\title{
O mito de Hércules: entre quadrinhos e cordéis
}

\author{
Leni Ribeiro Leite \\ Universidade Federal do Espírito Santo (UFES) \\ leni.ribeiro@gmail.com \\ Thayrynne Coutinho \\ graduada - Universidade Federal do Espírito Santo (UFES) \\ thayrinne_32@hotmail.com
}

RESUMO: O presente trabalho objetiva pensar o mito de Hércules no quadrinho de Ortega (2012) e no cordel de Marco Haurélio (2013), em comparação com as Metamorfoses, de Ovídio, tendo como objetivo sua realização dentro da dinâmica do ensino de literatura. Para tanto, nos valemos das considerações de Mortatti (2014; 2001) e Dalvi (2013a, 2013b) sobre o ensino de literatura no ensino básico, de Grijó (2017) sobre adaptação de obras literárias, e de Alves (2013) sobre literatura de cordel. Entendemos que a contraposição entre diferentes produções literárias possibilita que o aluno compreenda as adequações genéricas, ao mesmo tempo em que depreende as peculiaridades de cada gênero e de cada forma de circulação do texto na sociedade contemporânea.

Palavras-chave: Hércules; Quadrinhos; Cordel; Ensino de Literatura; Metamorfoses.

\section{The myth of Hercules: between comic books and cordel literature}

\begin{abstract}
This paper aims at ways to introduce Classical Literature into middle school by using Ovid's Metamorphoses compared to Ortega (2012) and Marco Haurélio's (2013) adaptations of the myth of Hercules. We based our work on Mortatti (2014; 2001) and Dalvi's (2013a, 2013b) discussion of the context of literature teaching in Brazil, Grijó's (2017) thesis on comic book adaptations of literary canon, and Alves' (2013) approach of Cordel Literature. This article defends that introducing and discussing such literature in regular schools, in parallel with other literary genres, allows students not only to access this kind of literature, but also to understand the differences between the genres and their circulation.
\end{abstract}

Keywords: Hercules; Comics books; Literature teaching; Metamorphoses. 


\section{Introdução}

Hércules, como personagem que vive diversas peripécias, foi representado ao longo dos tempos sob diferentes perspectivas. Na Antiguidade, dentro de um tipo de fazer literário essencialmente imitativo1, podemos citar as peças Héracles, de Eurípides, Héracles furioso, de Sêneca, e as próprias Metamorfoses, de Ovídio. $\mathrm{Na}$ Contemporaneidade, lembramos, como exemplo, a adaptação cinematográfica da Disney, de 1997, dirigida por Ron Clements e John Musker, e também o filme de 2014, dirigido por Brett Ratner, além da longa tradição de adaptações do herói no cinema italiano. Assim, em um perene legado de representação e reformulação da figura de Hércules, as multiplicidades de leituras mantêm vivas, ainda que, muitas vezes, sob uma nova roupagem, o mito.

Embora a tradição clássica esteja presente na esfera cotidiana, há pouca menção à cultura clássica, especificamente à greco-romana, nos documentos oficiais que regulamentam o ensino de literatura, tanto no fundamental quanto no ensino médio. Para Fortes e Miotti (2014, p. 158):

os Parâmetros Curriculares Nacionais (Ensino Médio), parte II: linguagens, códigos e suas tecnologias (2000) citam o grego e o latim em pouquíssimas passagens, e, em geral, somente para apresentarem comentários laterais sobre essa cultura.

Dessa forma, buscando uma abordagem diferente da tradição clássica, propomos neste trabalho o uso, em sala de aula, do mito de Hércules em Os doze trabalhos de Hércules, de Monteiro Lobato, adaptado para os quadrinhos por Ortega (2012), e do cordel de Os 12 trabalhos de Hércules, de Marco Haurélio (2013), em comparação com as Metamorfoses, de Ovídio, tomada como obra base. Intencionamos articular a leitura dos textos adaptados com o texto ovidiano, possibilitando aos alunos de sexto e sétimo ano do ensino fundamental o reconhecimento dos elementos clássicos aparentes nos textos adaptados, bem como das estruturas presentes na epopeia do poeta romano. Esta articulação seria realizada por meio da leitura em sala de aula das obras selecionadas, sob mediação do professor, visando trazer o texto literário para o centro das aulas.

Entendemos que a figura do professor como mediador da leitura literária é fundamental para o processo de interpretação desses textos, tendo em vista as particularidades de cada obra. Para Girotto e Souza (2014, p. 6) “cada gênero (...) exige de seu leitor um processo no qual ele realiza um trabalho ativo de

\footnotetext{
${ }^{1}$ Para Cesila (2014, p. 13), "a imitação era, portanto, condição para a escrita literária, não um defeito ou vício" em que "o escritor devia imitar os grandes modelos do passado, mas no sentido de utilizar material verbal e conteudístico dos mesmos de maneira criativa, competindo com os modelos e tentando, se possível, fazer melhor que eles, superá-los".
} 
compreensão e interpretação, a partir de seus objetivos, de seu conhecimento sobre o assunto, sobre o autor". Isto é, a forma de ler os cordéis, gênero que se realiza oralmente, é diferente da de ler quadrinhos, que se organizam por meio de uma sequência de quadros, e se distingue, também, da maneira de ler uma epopeia, texto narrativo em versos. Uma das estratégias propostas pelas autoras, denominada oficina de leitura (GIROTTO; SOUZA, 2014, p. 13-16), e que achamos frutífera para utilização no trato tanto do quadrinho quanto do cordel, inicia-se com a leitura em voz alta do professor: ao ler e intervir em muitos casos na leitura, o docente possibilitaria que os alunos entrassem em contato empiricamente com a obra, caso "ele [o professor] estabeleça em sua rotina não só momentos de leitura individual, mas também espaços em que molde o ato de ler" (GIROTTO; SOUZA, 2014, p. 14). Saber ler os textos influencia diretamente na interpretação das obras por parte dos alunos, e entendemos, portanto, que o papel do professor, para além de mediador, é também o de viabilizar o contato dos alunos com diferentes formas de ler e compreender os textos literários.

\section{A literatura na sala de aula: uma proposta}

A defesa da necessidade da presença e do acesso aos textos da Antiguidade Clássica na escola básica parte da compreensão da instituição escola como um espaço democrático e de inserção. Como a temos hoje, a escola surge, segundo Mortatti (2014, p. 24), logo após o fim da ditadura, em um período de organização social em que se denunciavam as práticas e as concepções antigas de ensino. Assim, pesquisadores e profissionais da área da educação debateram meios para a superação da "crise na educação" em busca de uma nova forma que fosse, diferentemente da anterior, mais democrática. Esse movimento possibilitou repensar o ensino de literatura no âmbito escolar, já que

as relações entre educação e literatura se tornaram temas de discussão e objetos de pesquisa e estudos sistemáticos produzidos por pesquisadores da área dos estudos literários no diálogo com as ciências da educação (MORTATTI, 2014, p. 25).

Citamos, como exemplos deste posicionamento, Candido (1987), para quem a literatura é essencialmente humanizadora, porque permite despertar e desenvolver no sujeito um olhar diferente em relação ao outro, em reconhecê-lo como igual (CANDIDO, 1987, p. 180), além de ser parte importante na construção do sujeito; e, ainda, Mortatti (2014, p. 29), que entende o ensino de literatura, assim como a educação no geral, como direito humano e fundamental para formação dos alunos. 
Essas discussões tinham por objetivo distanciar-se das práticas resumidas em ensino de história da literatura, na categorização das obras e de seus autores, ou no uso de textos como pretextos para o ensino de gramática, do bem falar o português e de valores moralizantes, sem que as particularidades das obras fossem questão principal (MORTATTI, 2014, p. 24). A autora discorre sobre como o trabalho com a literatura era feito por meio "do livro didático, aspectos de análise literária e (fragmentos de) textos de autores consagrados da literatura brasileira ou se estudavam livros de coleções destinadas ao público juvenil, acompanhados de 'fichas de leitura'" (MORTATTI, 2014, p. 36), em que pouco ou quase nenhum trabalho com o texto literário em si era feito. Por ser responsável pelo ensino da língua e da literatura, já que na nossa sociedade a alfabetização acontece em âmbito escolar, a escola configura-se como uma instância ideológica que "estabelece para que, porque, como, o quê, quando, onde e quem lê" (MORTATTI, 2014, p. 49), legitimando, no processo, leituras e obras.

Se a escola é uma das instâncias que legitimam o literário, a inserção de produções literárias que não são necessariamente as consideradas canônicas (tanto no âmbito da prosa quanto da poesia) promove uma dinâmica que possibilita pensar não apenas no acesso à literatura, mas também no reconhecimento de outras formas de produção. Ao mesmo tempo, porém, a escola é, muitas vezes, o único espaço que oferece oportunidade a um aluno menos privilegiado de acesso ao mundo dos clássicos, e, para muitos, acessar tal capital cultural é também uma tentativa de desnivelar as desigualdades sociais. O motor da atividade aqui proposta é justamente oferecer o acesso aos clássicos sem torná-los único repositório do saber, sem entendê-los como especiais, melhores ou superiores a outras formas de produção cultural tidas como populares, mas ver o clássico como apenas mais um elemento ao qual todos podem ter acesso. Essa dupla demanda é atendida na medida em que nos propomos a pensar o ensino de Metamorfoses, de Ovídio, a partir dos versos 98272 presentes no canto IX, que retratam o destino de Hércules, em articulação com a obra Os doze trabalhos de Hércules, de Monteiro Lobato adaptada para os quadrinhos por Ortega, e Os 12 trabalhos de Hércules de Marco Haurélio, um cordel, em um movimento em que

os valores do mundo clássico poderão ser motivo de discussão dos valores do nosso mundo, cujo conhecimento é franqueado também quando nos colocamos diante de nossas origens: indígenas, africanas, européias, asiáticas, clássicas, múltiplas (FORTES; MIOTTI, 2014, p. 161).

A articulação entre essas produções literárias passa também pelo entendimento de que a imitação é "uma prática comum aos antigos, mas que 
também se revela atual, por exemplo, nas transposições da literatura antiga em outras semioses contemporâneas, como cinema, os quadrinhos, os videogames etc." (FORTES; MIOTTI, 2014, p. 157). A leitura mediada pelo professor aconteceria, em um primeiro momento, a partir das obras adaptadas, para posteriormente chegar aos trechos da epopeia, já que o mito do herói representa apenas metade do canto. Dessa forma, o aluno teria contato prévio com o mito por meio do quadrinho e do cordel, antes de finalmente adentrar a obra de Ovídio, para assim possuir mecanismos para compreender a maneira como as façanhas do herói são construídas pelo poeta romano. Para além disso, a contraposição entre cada produção tornaria possível ao aluno perceber as particularidades e diferenças de cada meio, a depender do gênero e do público.

A opção por trabalhar com essas obras foi também fruto da nossa reflexão sobre o que pensa Dalvi (2013a) acerca das dez teses de Aguiar e Silva, revisitadas pela pesquisadora, ao propor, a partir delas conjecturas para a escolha e emprego das produções literárias no dia-a-dia da sala de aula. Dentre elas, destacamos duas: as teses II e IV.

A primeira, denominada "a centralidade do texto literário no ensino de língua", desloca o texto literário do seu lugar muitas vezes periférico da aula de literatura, em que se sobressaem a utilização de fragmentos e a ênfase na história da literatura. Em nossa proposta, o ensino de literatura deixa de ter um caráter utilitário como "ler para fazer exercício de interpretação, para estudar itens de conteúdos" (MORTATTI, 2001, p. 51) e passa a ser encarado como espaço em que a fruição do texto literário e suas idiossincrasias sejam os elementos centrais durante a aula. Para Dalvi (2013b, p. 124), a mutilação dos textos literários consolida três inverdades: 1) a de que acessar ou compreender os textos é difícil e que, portanto, seria necessário buscar outros caminhos para que a obra possa ser aplicada em sala de aula; 2) a de que alunos, principalmente os de escola pública e/ou do interior, não possuem capacidade de lidar com a suposta complexidade dos textos considerados como alta literatura e por isso necessitam de facilitadores; e, por fim, 3) a de que os fins, aprender literatura, justificam os meios, o sacrifício dos textos e suas particularidades.

Ao trazer o texto literário para o centro das práticas propostas no ensino de literatura, a autora compreende que o

texto literário não deve ser considerado como uma área apendicular ou como uma área perifericamente aristocrática da disciplina de português, mas como o núcleo da disciplina, como a manifestação da memória e da criatividade da língua portuguesa (DALVI, 2013a, p.78). 
Principalmente durante o Ensino Fundamental II, em que se pressupõe um trabalho de aproximação com a literatura, o aluno deve ser estimulado e confrontado com textos que exijam o seu esforço enquanto leitor para que possua subsídios para chegar ao ensino médio com conhecimentos prévios para o trabalho com a literatura (DALVI, 2013a, p. 74). Apresentar aos alunos de Ensino Fundamental II uma epopeia clássica não é impossível, e eles são capazes de fazêlo, dados materiais e auxílios adequados.

A segunda tese, denominada "a nuclearidade do texto no ensino de literatura, em articulação com diferentes linguagens, suportes e circuitos", sugere, sem que o texto deixe de figurar como elemento fundamental, a articulação deste com outras produções culturais tais como filmes, músicas ou quadrinhos, em um movimento que possibilite que o aluno entre em contato com diferentes tipos gêneros, suportes e formas de apresentação (DALVI, 2013a, p. 78). Assim, proporcionar ao aluno o contato com a produção oriunda da Antiguidade Clássica por meio da mitologia e, ao mesmo tempo, contrapor com produções contemporâneas - com uma obra de mesmo campo semiótico como o cordel, e outra de diferente, o quadrinho -, o ajudaria a "reconhecer que a mudança de suporte e de modos de apresentação implica alteração recepcional" (DALVI, 2013a, p. 82). Embora haja uma questão relacionada aos quadrinhos e, neste caso, uma adaptação em quadrinhos como produção de massa ligada à lógica do capital, em que muitas vezes o caráter comercial se sobrepõe ao caráter estético, ao promover uma ligação entre as produções populares, o texto literário e o aluno, a escola explora a interseção entre essas produções, sem que essa aproximação banalize o caráter estético das obras, mas proponha um olhar crítico sobre a indústria cultural (DALVI, 2013a, p. 76).

Sob muitos aspectos, sendo pensadas especificamente para o público infanto-juvenil, as adaptações são vistas como porta de entrada para os alunos, um caminho que o sujeito poderia facilmente trilhar sem se confrontar com obstáculos, como os elementos formais e estruturais de uma obra (GRIJÓ, 2017, p. 59). Por isso, em geral, a recusa da adaptação se dá por meio do impasse entre a compreensão dessa como uma redução do material original e da percepção desse material como válido para o ensino de literatura. Apoiamo-nos na ideia de que, para enxergar a adaptação como processo válido e considerar o seu espaço na sala de aula como produtivo, é necessário compreendê-la como produto outro, que não representa a leitura propriamente dita do original no qual se baseia, mas que significa, enquanto uma produção outra, uma experiência literária diferente. Sem dúvidas, ler a adaptação em quadrinhos de Dom Casmurro, por exemplo, não é ler Dom Casmurro; mas é também uma experiência literária. Para Stam (2006, p. 24), a adaptação pode ser entendida a partir dos estudos culturais como 
parte de um espectro de produções culturais niveladas e, de forma inédita, igualitárias. Dentro de um mundo extenso e inclusivo de imagens e simulações, a adaptação se torna apenas um outro texto, fazendo parte de amplo contínuo discursivo.

Por isso, essa produção, enquanto uma adaptação, se configuraria dentro das diversas manifestações do literário.

A articulação aqui proposta entre Monteiro Lobato, Marco Haurélio e Ovídio parte também do que dizem os Parâmetros Curriculares Nacionais (PCN), de 1998, em que o ensino de literatura é entendido como objeto "dentro de certas restrições de natureza temática, composicional e estilística, que os caracterizam como pertencentes a este ou aquele gênero". As Metamorfoses, de Ovídio, composta por quinze cantos, desenvolve episódios mitológicos, sem que haja um fio condutor entre eles (LEITE, 2016, p. 31). A escolha dessa obra em detrimento de outras se deve ao seu teor mitológico e à sua narratividade em episódios contidos em si mesmos, que tornam possível a leitura de um deles sem quebra do fluxo narrativo ou necessidade imediata de leitura dos demais cantos, aliados à intenção de trabalhá-la em conjunto com o quadrinho e o cordel.

\section{Os doze trabalhos de Hércules, de Monteiro Lobato}

A proposta de confrontar o texto literário com a adaptação em quadrinhos parte das características levantadas por Galo (2015, p. 29) de que esse meio possui uma estrutura narrativa e que, por isso, apresenta elementos próprios dessa modalidade: tempo, espaço, personagem, narrador e enredo. A oportunidade de abordar as HQs na sala de aula teve como ponto de partida a inclusão dessa produção literária em 2006 no Programa Nacional da Biblioteca na Escola PNBE, responsável por selecionar, distribuir e comprar os livros para os acervos escolares. Desde então, as adaptações em quadrinhos ganharam espaço na sala de aula (GALO, 2010, p. 35). A autora observa que, embora inicialmente as obras fossem vistas pejorativamente apenas como adaptações, ao longo dos anos, as produções concebidas em forma de quadrinhos também obtiveram o seu lugar. Com essa medida, além de desenvolver novos meios para abordagem pedagógica, a inserção no ensino de uma multiplicidade de gêneros e plataformas favorece a formação crítica de novos leitores (GALO, 2010, p. 34).

Trazer a obra Os doze trabalhos de Hércules, de Monteiro Lobato sob o formato dos quadrinhos não foi uma escolha arbitrária. Pelo contrário, pauta-se em um posicionamento claro frente à maneira como o autor é abordado no ensino regular, pois a literatura lobatiana precisa ser discutida. Rocha (2015) discorre sobre os ideais eugenistas construídos nas produções lobatianas, que são, 
necessariamente, o pensamento de um tempo: "a cada tempo cultural existem fatores que determinam um modo de pensar, de agir e de compreender o mundo. A literatura não foge a esse contexto" (ROCHA, 2015, p. 11). Compreender Lobato como um homem de seu tempo, em um contexto em que os discursos eugenistas eram naturalizados, e, portanto, não questionados, não corresponde a absolvê-lo ou excluí-lo completamente da lista de leituras do ensino básico. Se, por um lado, sua permanência sem que haja reflexão é problemática, por outro, sua total exclusão torna-se igualmente problemática na medida em que retira da escola, espaço institucional de ensino, a possibilidade de discussão e problematização. Assim, a subtração de Lobato também nega ao aluno o direito de conhecer e participar dos questionamentos em torno da obra e da figura do autor. Assim, concordamos com o posicionamento de Rocha, que propõe:

(...) que a obra seja utilizada à luz da consciência contemporânea forjada nas lutas de combate ao racismo como instrumento de aguçamento da percepção e despertar uma nova consciência cidadã, que passa pela superação dos estereótipos elucidados na literatura lobatiana (ROCHA, 2015, p. 12).

A obra Os doze trabalhos de Hércules, de Monteiro Lobato, adaptada para os quadrinhos por Denise Ortega, ancora-se na versão do mito em que, sob influência de Hera, esposa de Zeus, o herói comete a pior das atrocidades, ao matar sua esposa e filhos em um rompante de fúria. Após ouvir o oráculo, Hércules segue em sua peregrinação para completar os doze desafios, para, enfim, pagar pelo seu erro. A narrativa inicia-se com uma intervenção de Emília "Se não fosse eu... quer dizer, a gente, para lhe dar bons conselhos, usando mais o cérebro que os músculos, ele não teria cumprido todas aquelas terríveis tarefas" (ORTEGA, 2012, p. 3) e, desde esse momento, é sinalizado que, embora se pretenda narrar as aventuras de Hércules, não há compromisso de fidelidade com o mito que se usa como base - o que possibilita o trabalho com diferentes versões da história sob o ponto de vista pedagógico, o que é em si característica do gênero mito. Se em Ovídio a morte de Hércules acontece nos versos 98 a 158 do nono canto, na obra lobatiana o leitor descobre o desfecho da história logo nas primeiras páginas: é dona Benta que conta para Narizinho de forma resumida as aventuras de Hércules e, principalmente, a morte do herói, o que é um dado importante, já que, assim como na Antiguidade, em que a suposição do conhecimento prévio dos mitos compõe o jogo da criação literária, na história criada por Lobato e adaptada por Ortega, essa suposição também se faz presente. Esse movimento faz com as histórias sejam desenvolvidas dentro do ecossistema do Sítio do Pica-Pau Amarelo, que 
pode ser interpretad[o] como integrante da proposta lobatiana de romper fronteiras entre o plano real e o plano maravilhoso, bem como entre planos cronológicos: Pedrinho, Emília e Visconde convivem com Péricles, Aspásia, Hércules, Medéia e Teseu - ou seja, acontece a mesma mistura de personagens realistas e maravilhosos (TOPAN, 2007, p. 26).

No sétimo desafio, por exemplo, é Emília quem sugere a Teseu que a melhor forma de sobreviver ao labirinto do Minotauro é utilizando uma linha de costura para demarcar o caminho percorrido, e é Pedrinho que, repetidas vezes, auxilia na captura do touro ou javali por meio das armadilhas que ele aprendeu a fazer no Sítio. É uma mescla entre a intervenção da trupe do sítio e o mito, préestabelecido, que constrói a narrativa.

Nos quadros referentes ao destino do herói, dona Benta nos conta outra história: Dejanira conscientemente embebeda a túnica para Iole, descrita e desenhada como uma moça bonita, mas esquece que a túnica seria vestida originalmente por Hércules.

Em comparação, na adaptação, o que move as ações de Dejanira é a vingança, enquanto, em Ovídio, Dejanira é enganada e envia a túnica com objetivo de restabelecer o relacionamento amoroso com o herói:

Entre muitas ideias, decidiu-se por enviar a Hércules a veste impregnada com o sangue de Nesso, o que tornaria possível devolver a força a qualquer amor enfraquecido. Ela própria, desconhecedora de que o presente estava envenenado, entrega a Licas, para que este o repasse ao homem a quem está endereçado, juntamente com brandas palavras. O herói, sem saber, pega e veste a roupa envenenada sobre os ombros² (OVIDIO, Metamorfoses, 9. 152158).

A jornada inicia-se com a vontade de Pedrinho de retornar à Grécia ${ }^{3}$. Ele, juntamente com Emília e Visconde de Sabugosa, que estão equipados com o pó de pirlimpimpim, viajam pelo tempo para o exato momento em que Hércules parte para o primeiro trabalho: o confronto com o leão da Nemeia. Nota-se aqui

\footnotetext{
${ }^{2}$ In cursus animus uarios abit: omnibus illis/praetulit inbutam Nesseo sanguine uestem/mittere, quae vires defecto reddat amori/ Ignaroque Lichae, quid tradat, nescia, luctus/ipsa suos tradit blandisque (miserrima!) uerbis/dona det illa uiro, mandat. Capit inscius heros/induiturque umeris Lernaeae uirus echidnae. (Ov., Met.,9.152-158). A tradução dos trechos da obra ovidiana é de José Ernesto e Fernando Coelho (in OVÍDIO, 2017).

${ }^{3}$ A história que lida com a jornada do Pedrinho, assim como da turma inteira, para a Grécia, está presente na obra Minotauro (1939) de Lobato.
} 
um expediente da épica: apesar da narrativa iniciar com uma introdução, como já comentado, os personagens chegam na ação in medias res.

Essa estrutura é compreendida por Leite como uma narrativa que se inicia com a história em curso: "a narrativa não parte do que seria considerado o início da história; o leitor encontra as personagens já lidando com a intriga, parte da qual o leitor só conhecerá por meio de narrações das próprias personagens ou em flashbacks" (LEITE, 2016, p. 19). Assim, a trupe do Sítio só entende as motivações de Hércules quando o próprio herói, ao ser confrontado por Emília, comenta a razão pela qual continua realizando os desafios, embora saiba que a responsável por seus males seja Hera. Nas Metamorfoses, os desafios superados por Hércules são enumerados no seu discurso final, quando extravasa seus sentimentos:

Se, como inimigo, te causo piedade, se para ti estou com um aspecto horrível, tira-me esta vida horrenda, marcada por tanto sofrimento e por tamanhos trabalhos, a morte, assim será um presente, para mim, um presente típico de madrasta. Ou, por acaso, não fui eu que venci o repugnante Busíris, que sujava os templos com o sangue dos estrangeiros? Não fui eu que arrebatei o feroz Anteu da força da mãe? Por acaso a forma tríplice de Cérbero me amedrontou? Por acaso não foram estas mãos que comprimiram os cornos do potente touro? Elís manterá a fama de meu trabalho, assim como as ondas Estinfálide e também o bosque de Partênio, tudo isso relacionado com a minha virtude. Não fui eu que, ornado com o cinturão de outro termodontíaco, obtive as maçãs guardadas sob os cuidados do insone dragão? Não resisti ao Centauro, ao devastador javali da Arcádia? Será que foi inútil derrotar a Hidra, de cujas feridas cresciam duas cabeças exatamente iguais? Não é verdade, então, o que eu vi: os cavalos trácios, canibais, alimentados com sangue humano, os estábulos repletos de corpos esquartejados? Não é verdade, então, que aniquilei o seu dono e os próprios animais assassinos? Eu carreguei o céu sobre estes ombros. A esposa de Júpiter está cansada de ordenar, e eu, de cumprir suas tarefas ${ }^{4}$ (OVIDIO, Metamorfoses. 9. 178-199).

\footnotetext{
${ }^{4}$ Vel si miserandus et hosti/ hoc est, si tibi sum, diris cruciatibus aegram/ inuisamque animam natamque laboribus aufer/ hoc mihi munus erit; decet haec dare dona nouercam/ ergo ego foedantem perigrino templa cruore/ Busirin domui saruoque alimenta parentis/ Antaeoeripui? Nec me pastoris Hiberi/ forma triplex, Nec forma triplex tua, Cerbere, mouit?/Vosne, manus, ualidi pressistis cornuatauri?/ Vestrumopus Elis habet, uestrum Stymphalides undae/ Partheniumque nemus? Vestra uirtute relatus/ Thermodontiaco caelatus balteus auro/ pompaque ab insomni concustodita dracone?/Nec mihi Centauri potuere resistere, Nec mi/ arcadiae uastator aper? Nec profuit hydrae/crescere per damnum geminasque resumere uires?/ quid tum? Thracis equos humano sanguine pingues/plenaque corporibus laceris praesepia uidi/uisaque deieci dominumque ipsosque peremi/ His
} 
Outro expediente épico encontrado na narrativa em quadrinhos é a presença do divino, pois "os deuses não apenas são personagens comuns nas epopeias, como, por vezes, interferem diretamente na ação e têm algum tipo de contato com os mortais" (VASCONCELLOS, 2014, p. 22): seja a própria Hera, que confabula com Euristeu para dificultar os caminhos de Hércules, seja Palas Atena que procura ajudar o grupo na empreitada por intermédio de seu ajudante, Minervinho.

Essa realização do divino também aparece em outra instância, dessa vez cômica, quando, ainda escondidos, a trupe do Sítio do Picapau dá dicas para Hércules de como derrotar o temido leão. O herói, por sua vez, acredita que as vozes são dos deuses - é a partir dessa interação que, juntos, eles embarcam em busca da realização dos doze trabalhos. Dentro dessa história, observamos a maneira como a invulnerabilidade do leão é transmitida para o quadrinho: as onomatopeias que saltam dos limites determinados pelos enquadramentos da obra, demonstrando que as flechas lançadas pelo herói ricocheteiam no leão, portanto não o machucam e, logo no quadrinho seguinte, o animal está com cara de desdém, fingindo sono. É com os recursos de que essa obra semiótica dispõe, os limites entre quadros e as onomatopeias, que uma das características do leão é transmitida para a adaptação.

Algumas repetições de estruturas e expressões como "Aurora dos dedos róseos" são cativas na narrativa épica marcada por uma tradição oral, mas, posteriormente, tornaram-se um recurso próprio do gênero (LEITE, 2016, p. 19). Em determinado momento, no quadrinho, podemos ver uma transposição dessa estrutura na figura de Febo Apolo, que, em sua carruagem, demonstra a mudança do tempo.

Em outros pontos da narrativa, no entanto, essas expressões são feitas por pequenos balões, que ora narram, ora transmitem a passagem de tempo. É por meio de um recordatório que, em dado momento, por exemplo, quando Hércules completa o quinto trabalho, a limpeza das cavalarias de Áugias, o herói destrona o rei por não cumprir com a promessa feita no início do desafio: disponibilizar dez por cento dos cavalos presentes no estábulo para o semideus.

Composta por um costurar de mitos, as Metamorfoses não possuem uma linha narrativa: "a narração começa com a própria formação do universo e segue até praticamente a contemporaneidade do poeta" (LEITE, 2016, p. 31). Assim, seus cantos são formados tanto por histórias que não possuem relação umas com as outras, como o canto IV, destinado aos mitos das Mínias, de Píramo e Tisbe, e as que possuem relação entre si, como o terceiro canto, que envolve o ciclo tebano.

Elisa iacet moles Nemeaea lacertis/ hac caelum cervice tuli. Defesa iubendo est/ saeua Iovis coniunx: ego sum indefessus agendo. (Ov., Met., 9.178-199). 
Leite (2016, p. 32) observa que apenas as partes extremas, o início e o final, possuem alguma lógica cronológica. Já na adaptação de Ortega, os desafios parecem se suceder linearmente, embora também seja entrecortada com outros mitos. Temos um vislumbre das origens de Medusa e Medeia, esta como uma feiticeira que ajuda a curar a trupe em momentos de necessidade, e aquela como uma horrenda monstruosidade desenhada com os cabelos de cobras, asas de bronze e feições animalescas, que é derrotada com ajuda de Hermes e de ninfas com um chapéu invisível. Após a derrota da górgona, Pegasus é visto voando pelos céus. Essa anedota é contada pelo Visconde quando este encontra Perseu, ao retornar para pegar os pelos do leão de Nemeia.

Por fim, consideramos fundamental dialogar com os alunos acerca da personagem tia Nastácia. Ainda que ela esteja apenas nos quadros iniciais, porque são poucas páginas destinadas ao que acontece antes da viagem da trupe à Grécia, quando a personagem surge na narrativa, está sempre cuidando dos afazeres domésticos. Nesse aspecto, uma questão importante a ser levantada reside em qual é, então, sua função desempenhada na história e, também, no ecossistema criado por Lobato. A discussão em relação aos problemas da obra lobatiana precisa ocorrer tendo a obra como ponto de partida e chegada: como a presença da personagem reflete os acontecimentos narrados, qual é o papel dela, de que forma ela é construída na obra. Antes de tudo, é a conversa sobre o texto literário como centro das discussões.

Após o contato com o mito de Hércules através dos quadrinhos, os alunos verão sob a forma de uma narrativa literária, o cordel.

\section{Os 12 trabalhos de Hércules, de Marcos Haurélio: uma proposta com a literatura de cordel}

Alves (2013) defende a presença da literatura de cordel na escola, dentre as diversas que já circulam nesse espaço. A autora pontua que "devemos ler e levar ao espaço escolar toda manifestação artística, de qualquer grupo ou classe social, veiculadas por diferentes suportes - oral ou escrito" (ALVES, 2013, p. 36), tendo em vista o movimento de compreender as outras produções literárias e artísticas como procedimentos legítimos que carregam em si elementos culturais. Oriunda de uma prática oral que se realizava por meio de apresentações (ALVES, 2013, p. 39), a literatura de cordel carrega as idiossincrasias próprias de uma produção oral, que, embora distante temporalmente, se aproxima das condições iniciais de produção das epopeias, tal como a Ilíada e Odisseia dos aedos. Os 12 trabalhos de Hércules (2013), de Marco Haurélio, ilustrado por Luciano Tasso, é uma obra composta por quatorze cordéis, uma introdução e um epílogo, que inicia e finaliza a contação de histórias; e os doze desafios do herói, que são desenvolvidos em quadras ("O feroz leão de Nemeia”; “O cinto de Hipólita, a 
rainha das amazonas"; "As maçãs douradas do país das Hespérides"), sextilhas ("Os pássaros do lago Estínfalo"; "Os cavalos do tirano Diomedes"; "A captura de Cérbero, o cão do inferno"), setilhas ("Introdução"; “O javali de Erimanto"; "Epílogo"), oitavas ("A cerva cerinita"), e décimas ("A hidra de Lerna"; "Os imundos estábulos de Augias"; “O touro de creta"; “Os bois do gigante Gerião") com rimas variadas.

Já na introdução, podemos ver vários expedientes épicos. A abertura, "Musa dos antigos vates/ que de Homero foi guia/ peço vossa intercessão/ para cantar a poesia/ a saga de um semideus/ filho de Alcmena e Zeus/ Emblema de valentia", é uma espécie de proêmio em que o narrador invoca as musas dos antigos uates, referindo-se ao narrador do gênero épico, que outrora conduziram os versos de Homero. O proêmio épico é descrito por Leite $(2016$, p. 19) como "abertura do poema em forma de proposição, em que se descreve em poucos versos o tema que será tratado no poema, seguida de invocação, em que se pede o auxílio a uma ou mais divindades para a realização da empreitada". O narrador dos cordéis nos apresenta, no proêmio, que cantará as desventuras do semideus, e, recorrentemente, se coloca frente ao leitor, seja já na introdução, quando indica o caminho a ser seguindo, "portanto, caro leitor, vamos a nossa viagem/ Porque Apolo nos acena/ da dourada carruagem", seja ao se ligar à tradição oral por cantar, e não escrever, como também ocorre nas epopeias clássicas.

No cordel, já será possível observar as variantes da história e lembrar que é característica do mito a existência de variação. Diferente do proposto por Lobato, por exemplo, a origem do herói é outra, já que, por não ter nascido primeiro, sofreu as represálias de Euristeu, e também de Hera, que intercedeu pelo primogênito. Outro ponto que pode ser trabalhado em relação ao gênero, para além da versificação e afins, é o teor cômico que alguns dos cordéis assumem. No cordel destinado a contar sobre o leão de Nemeia, temos os seguintes versos: “Filha de Equidna e Orto/ Esta terrível criatura/ Como os pais, terríveis monstros/ Levava o povo à loucura/ Pois passara várias vezes/ Pela fila da feiura"; ou, em outro momento, "Porém o golpe não fere/ pois é mais duro que o aço/ Hércules, então, exclama:/ tu achas que eu sou palhaço? / depõe as armas e diz: vamos resolver no braço!"; ou ainda em "Hidra de Lerna", nos versos: "O herói se aproxima do lugar/ Em que vive essa fera tão horrenda/ sem temer bafo quente ou reprimenda./ mas ao ponte de quase desmaiar". Esses trechos não apenas exploram a comicidade das situações enfrentadas por Hércules, como também abrem espaço para o debate em relação à regionalidade, importante para a constituição do gênero cordel. Como produção oriunda do Nordeste, que possui linguajar próprio, o narrador emula, ao contar as peripécias do herói, uma fala popular, que difere significativamente do tom utilizado nos quadrinhos e nas Metamorfoses. Além disso, o narrador interage constantemente com as 
expectativas do seu leitor quando, nos versos "o leitor, a esta altura/ deve ter imaginado/ que a região de bistonia/ Hércules será mandado (...) e de fato tem razão/ que pensou dessa maneira", alude a uma situação da qual ele sabe que os leitores têm conhecimento, assim como já comentado em relação às produções da Antiguidade gregas e romanas. Em outro momento, o narrador tenciona o próprio fazer poético do cordel em "O javali de erimanto", nos versos "o erimanto é castigado/ por um javali perverso/ que, se não mente o meu verso/ era um ser gigantesco", quando brinca com a tentativa de encaixar um termo que caiba na versificação.

Em suas considerações finais, Alves critica a maneira como a literatura de cordel é apresentada nas escolas, já que muitas vezes "escrevem-se gramáticas em cordel, folhetos com ensinamentos de histórias, geográfica, ecologia, primeiros socorros e muitos outros conteúdos" (ALVES, 2013, p. 47) sem que a narrativa literária em si seja trabalhada e valorizada. O cordel de Marcos Haurélio não é uma narrativa apenas, mas uma narrativa mitológica, ancorada em várias tradições narrativas clássicas e brasileiras, que podem ser exploradas antes da leitura da obra de Ovídio em si.

\section{Metamorfoses, de Ovídio: estratégias de leitura}

A tradução realizada por José Ernesto e Fernando Coelho do canto IX, das Metamorfoses, que utilizamos ao longo do presente artigo, é feita em prosa. Embora a tradução não esteja em verso como a versão original, sua leitura não se torna menos necessária. Como questões tradutórias não são o foco, e as convenções do gênero podem ser encontradas no trecho correspondente ao mito de Hércules, o acompanhamento da leitura pelo professor ainda possibilita o contato do discente com a fruição da épica em articulação com as adaptações. Os fragmentos do canto que envolvem o herói são o embate de Hércules e Aqueleu pelo amor da jovem Dejanira, o conflito entre Nesso e Hércules (vv. 98-272) e a sua morte (vv. 134-272).

Como estratégia para a leitura de textos literários na sala de aula, Girotto e Souza (2014) sugerem que o ensino da leitura deve ser "centrado em um conjunto de estratégias de leitura: conexões, inferência, visualização, questionamento, síntese e sumarização" (GIROTTO; SOUZA, 2014, p. 5). Essas estratégias podem ser escolhidas conforme a necessidade e o planejamento do professor, sendo fundamentais para que a leitura em si seja potencializada. Mais do que a leitura apenas pela leitura, o trabalho com o texto deve girar em torno de elementos e de estruturas necessários para a formação do aluno enquanto leitor. 
Destacamos brevemente como alguns desses recursos podem ser empregados ao decorrer da leitura do texto ovidiano. No embate entre Hércules e Aqueleu, este comenta com Teseu, filho de Netuno, as razões pelas quais se encontra mutilado. Inicialmente o confronto acontece por meio de um diálogo em que ambos tentam convencer o pai de Dejanira sobre quem seria a melhor opção para desposar a sua filha. Aqueleu enaltece sua linhagem: "não serei um genro enviado do litoral para ti, entre inimigos externos, mas antes parte dos teus, da sua gente, de tuas coisas"5; e Hércules, para se contrapor, relembra ao seu competidor suas façanhas e seu parentesco divino com Júpiter: "propiciar à noiva um sogro como Júpiter, além de seus trabalhos, como cumprimento das ordens da madrasta"6. Como o objetivo de Aqueleu é ser mais valoroso que Hércules aos olhos do pai de Dejanira, ele busca, através do argumento do herói, uma maneira de desmerecê-lo. Para atacar Hércules, Aqueleu se utiliza justamente do parentesco do semideus para desmoralizá-lo, já que um dado importante de suas origens é que ele possui dois pais, Júpiter e Anfitrião:

Tu dizes que és filho de Alcmena e de Júpiter, mas este ou não é o verdadeiro pai, ou, de outra forma, se faz por um crime, pois tu buscas um pai que se fez por intermédio do adultério, da tua própria mãe. Faz a tua escolha: Tu queres que Júpiter seja uma mentira ou preferes ser filho da vergonha?7 (OVIDIO. Met. 9, 23-26).

Nesse trecho podemos visualizar pontos que podem ser levados pelo professor para sala de aula: a maneira como, mesmo sem apresentação inicial sobre o herói, o diálogo, que serve como recurso para lembrar ao leitor qual a origem de Hércules, é ponto de partida do poema, e a forma como é construído o embate discursivo entre os personagens. Não cabe ao professor, nesse estágio da formação do discente, discutir minuciosamente sobre retórica, mas isso não o impede de mostrar e explicar como algumas estruturas são estabelecidas, já que a construção de argumentos é uma ferramenta que será cobrada do estudante em algum momento de sua trajetória escolar. A intenção é que, a partir das discussões e da leitura realizada por intermédio do professor, os alunos possam materializar a leitura, em outras palavras, compreender os requisitos para ler esse texto, pois, como indicam Girotto e Souza (2014, p. 4), "os alunos têm uma interlocução, quando há um trabalho de discussão que os leva a compreender o

\footnotetext{
${ }^{5}$ Nec gener externis hospes tibi missus ab oris, sed popularis ero et rerum pars una tuarum (Ov., Met., 9. 19-20)

${ }^{6}$ Ille Iouem socerum dare se famamque laborum et superata suae referebat iussa nouercae. (Ov., Met., 9.14-15)

${ }^{7}$ Nam, quo te iactas, Alcmena nate, creatum, Iuppiter aut falsus pater est, aut crimine uersus. Matris adulterio patrem petis. Elige, fictum esse Iovem malis, an te per dedecus ortum? (Ov., Met., 9. 23-26)
} 
que leram, e quando o livro é ofertado - os estudantes materializam a leitura, leem".

Nesse processo, estaríamos aplicando duas das estratégias de leitura destacada por Girotto e Souza (2014, p. 15): a conexão, ao confrontar o mito presente em Ovídio, com o conhecimento de mundo dos alunos, adquiridos tanto do contato prévio com o herói quanto do trabalho realizado por intermédio das adaptações; e a inferência, ao estimulá-los a perceber algumas informações que, embora não sejam ditas, fazem parte do jogo literário composto pelo poeta. Um exemplo disso é o estabelecimento da origem de Hércules por meio dos nomes Alceu e Anfritriônida, em referência aos pais do herói.

Em outro momento durante essa experiência de leitura e contato com o texto, os discentes precisam ser estimulados a formular perguntas em relação à leitura realizada para que elas possam “(...) ser respondidas no decorrer da leitura com base no texto ou com o conhecimento do próprio leitor" (GIROTTO; SOUZA, 2014, p.14). Esse movimento de confronto com texto é extremamente necessário, pois aproxima a obra do leitor na mesma medida em que estabelece uma relação com o literário que não é passiva. Por meio do questionamento, o aluno adquire a prática de investigar os meandros do texto literário.

Para finalizar, a sumarização, ação de indicar os pontos centrais da obra, e a síntese, impressões sobre os textos seriam organizadas em uma roda de conversa/leitura: os discentes trocariam suas percepções sobre os pontos importantes da obra (GIROTTO; SOUZA, 2014, p. 15), em um momento de troca de informações. Essas duas estratégias de leitura são construídas a partir da compreensão do todo, mas levam em consideração os pequenos elementos dentro da narrativa e, por isso, uma obra tão complexa quanto as Metamorfoses de Ovídio pode ser um ótimo meio para trabalhá-las dentro da sala de aula.

Em suma, as possibilidades de estratégias de leitura da epopeia ovidiana são muitas. O mais importante, ao final, é que os alunos façam aquilo que é o esperado em uma aula de literatura: leiam.

\section{Considerações finais}

Em uma tentativa de estabelecer uma relação intertextual entre os textos trabalhados, pretendeu-se, nesta proposta, uma articulação entre obras que, embora concebidas em temporalidades e gêneros diferentes, aproximam-se devido à temática mitológica das façanhas de Hércules. Assim, os cordéis de Haurélio, a adaptação de Ortega do texto lobatiano e o episódio mitológico de Ovídio construíram maneiras diferentes de apresentar o mito do herói. Enfrentando o paradoxo construído na escola, em que não se propõe a leitura de textos considerados difíceis, pois se acredita que o aluno não tenha capacidade para tal, e por isso, não há oportunidade de ensinar ao aluno estratégias para 
lidar com o estranhamento na leitura, fazem-se necessárias proposições que tenham como objetivo tencionar essa concepção. Somos concordes com Dalvi (2013a, p. 74) quando esta postula que o estudante precisa ser exposto a textos de "estéticas mais sofisticadas (o que está longe de querer dizer mais elitizadas) que exigirão seu esforço inter(ter)ventivo como leitor", ao mesmo tempo sem relegar a produção de massa à total negação. Pelo contrário, urge refletir sobre esse produto para compreender as relações acerca da inserção dessas obras em seus contextos literários.

\section{REFERÊNCIAS}

ALVES, José Hélder. O que ler? Por que?: a literatura e seu ensino. In: DALVI, Maria Amélia at ali (Org). Leitura de literatura na escola. São Paulo: Parábola, 2013. p. 35-50.

BRASIL. Ministério da Educação. Parâmetros Curriculares Nacionais (PCNs). Ensino Fundamental. Terceiro e quarto ciclos. Brasília: MEC/SEF, 1998.

BRASIL. Ministério da Educação. Programa Nacional Biblioteca da Escola. Brasília: MEC, 2006. Disponível em: http://portal.mec.gov.br/programanacional-biblioteca-da-escola. Acesso em 02 de junho de 2021.

CANDIDO, Antonio. Direitos humanos e literatura. In: RIBEIRO, A. C. F. (Org.) Direitos humanos. São Paulo: Brasiliense, 1987. p. 168-191.

CESILA, Robson Tadeu. Intertextualidade e Estudos Clássicos. In: SILVA, Gilvan Ventura da; LEITE, Leni Ribeiro (org.). As múltiplas faces do discurso em Roma: textos, inscrições, imagens. Vitória: Edufes, 2014. p. 10-22.

DALVI, Maria Amélia. Literatura na escola: propostas didáticas-metodológicas. In: DALVI, Maria Amélia et ali (Org). Leitura de literatura na escola. São Paulo: Parábola, 2013a. p. 67-97.

DALVI, Maria Amélia. Literatura na educação básica: propostas, concepções, práticas. Cadernos de Pesquisa em Educação, n. 38, p. 123-140, 2013 b.

FORTES, Fábio Silva; MIOTTI, Charlene Martins. Cultura clássica e ensino: uma reflexão sobre a presença dos gregos e latinos na escola. Organon, v. 29, n. 56, p. 153-173, 2014. 
GALO, Regina Aranda. Dos Livros para os Quadrinhos: as Quadrinizações de Obras Literárias na Sala de Aula. Revista de Ensino, Educação e Ciências Humanas, v. 11, n. 2, p. 33-41, 2010.

GIROTTO, Cyntia Graziella; SOUZA, Renata Junqueira. Estratégias de leitura: uma alternativa para o início da educação literária. Álabe, n. 10, p. 1-21, 2014.

GRIJÓ, Andrea Antolini. Quem conta um conto aumenta um ponto? Reflexões sobre as adaptações de clássicos da literatura para crianças e jovens leitores. 250f. Tese (Doutorado em Educação) pela Universidade Federal do Espírito Santo, Centro de Educação, 2017.

HAURÉLIO, Marcos. Os 12 trabalhos de Hércules. Ilustrações: Luciano Tasso. $1^{\circ}$ edição. São Paulo, Cortez Editora, 2013.

HÉRCULES. Ron Clements e John Musker. Estados Unidos: Walt Disney Pictures, 1997. (93 min.).

HÉRCULES. Brett Ratner. Estados Unidos: Paramount Pictures, 2014. (98 min.).

LEITE, Leni Ribeiro. Épica II: Ovídio, Lucano e Estácio. Campinas: Unicamp, 2016.

MORTATTI, Maria do Rosário. Literatura e escola: sobre a formação do gosto. $2^{\circ}$ edição. São Paulo: Martins, 2001.

MORTATTI, Maria do Rosário. Na história do ensino da literatura no Brasil: problemas e possibilidades para o século XXI. Educar em Revista, Curitiba, Brasil, n. 52, p. 23-43, 2014.

ORTEGA, Denise. Os doze trabalhos de Hércules: adaptada da obra de Monteiro Lobato. (Coleção Monteiro Lobato em quadrinhos). Ilustração: Luiz Podavin. São Paulo: Globo, 2012.

OVÍDIO. As metamorfoses. Organização de Mauri Furlan e Zilma Nunes. Florianópolis: Editora da UFSC, 2017

ROCHA, José Geraldo. Se te derem um limão, faça dele uma limonada: reflexões sobre racismo na obra de Monteiro Lobato. Revista Ciências Humanas, v. 8, n. 2, p. 7-13, 2015. 
STAM, Robert. Teoria e prática da adaptação: da fidelidade à intertextualidade. Ilha do Desterro: A Journal of English Language, Literatures in English and Cultural Studies, n. 51, p. 19-53, 2006.

TOPAN, Juliana de Souza. O "Sítio do Picapau Amarelo da Antiguidade": singularidades das Grécias lobatianas. 2007. Dissertação (mestrado) Universidade Estadual de Campinas, Faculdade de Educação, Campinas, SP. Disponível em: <http://www.repositorio.unicamp.br/handle/reposip/252452>. Acesso em: 13 dez. 2018.

VASCONCELLOS, Paulo Sérgio de. Definindo épica. In: Épica I: Ênio e Virgílio. Campinas: Unicamp, 2014, p. 11-29.

Data de envio: 05/03/2021 Data de aprovação: 08/06/2021 Data de publicação: 15/07/2021 